\title{
PENGGUNAAN MEDIA PEMBELAJARAN FILM DOKUMENTER PADA MATA PELAJARAN SEJARAH KEBUDAYAAN ISLAM (SKI) KELAS VIII C DI MTS KEBUNREJO GENTENG BANYUWANGI
}

\author{
Riza Faishol ${ }^{1}$, Ahmad Izza Muttaqin ${ }^{2}$, Mohammad Afton Fahmi Prayogie ${ }^{3}$ \\ Institut Agama Islam (IAI) Ibrahimy Genteng Banyuwangi, Indonesia \\ e-mail:1 1riza@iaiibrahimy.ac.id, 2izza@iaiibrahimy.ac.id, \\ 3yogikcoy@gmail.com
}

\begin{abstract}
Based on observations made by researchers at MTs Kebunrejo Genteng, it turns out that there are still many weaknesses and obstacles faced, especially in learning (SKI). This was strengthened based on the results of interviews with some eighth grade students, their understanding in the learning process was felt to be lacking because most of them assumed that subjects (SKI) were subjects that tended to be less interesting and boring, because students had to memorize years or names. figure. Because it is considered a boring subject which in the end has an impact on the students' lack of understanding in receiving the subject matter, this can be seen in the odd semester scores on the material of the Islamic dynasty. This can be proven from 34 students of which 14 students scored below the minimum completeness criteria (KKM), namely 7. Based on the above problems, the researcher intends to describe the problem by using a learning medium that can help students understand the learning material. The learning media used were documentary films. The results of research on the use of documentary film learning media in class VIII C students at MTs Kebunrejo Genteng are that students are easier to understand and memorize Islamic dinasty subject matter (Ayyubiyah), student interest in learning is better than before, and students can achieve the above score (KKM) that is the value 7.
\end{abstract}

Keywords : Usage, Learning Media, Documentary Film

\begin{tabular}{|c|c|c|}
\hline Accepted: & Reviewed: & Publised: \\
December 20 2020 & Januari 05 2021 & February 01 2021 \\
\hline
\end{tabular}

\section{A. Pendahuluan}

Dalam dunia pendidikan baik di lingkup lembaga sekolah atau madrasah, proses pembelajaran memang hal yang wajib ada karena itu merupakan keharusan atau syarat dalam menciptakan proses pembelajaran. Dalam proses pembelajaran sendiri tidak luput dari penggunaan metode, model dan strategi yang harus dilakukan oleh pendidik sebagai cara yang harus digunakan untuk menambah 
Riza Faishol, Ahmad Izza Muttaqin \& Mohammad Afton Fahmi Prayogie

efektivitas pembelajaran, baik pembelajaran umum maupun pembelajaran Pendidikan Agama Islam (PAI) (Dewi et al., 2019).

Tujuan utama pembelajaran adalah membuat siswa benar-benar belajar, yaitu tercapainya tujuan belajar untuk belajar (Astuti et al., 2020). Pendidikan dapat menjadi tolak ukur bagi kemajuan dan kualitas kehidupan suatu bangsa, sehingga dapat dikatakan bahwa kemajuan suatu bangsa atau Negara dapat dicapai dengan salah satunya melalui pembaharuan serta penataan pendidikan yang baik. Jadi, keberadaan pendidikan memiliki peran yang sangat penting dalam menciptakan kehidupan masyarakat yang cerdas, pandai, berilmu pengetahuan yang luas, berjiwa demokratis serta berakhlaqul karimah. Sedangkan pendidikan sendiri adalah usaha sadar dan terencana untuk mewujudkan suasana belajar dan proses pembelajaran agar peserta didik secara aktif mengemban potensi dirinya untuk memiliki kekuatan spiritual keagamaan, pengendalian diri, kepribadian,kecerdasan, akhlak mulia, serta ketrampilan yang diperlukan dirinya, masyarakat, bangsa dan Negara (Sisdiknas, 2003).

Permasalahan yang ada dalam pembelajaran contohnya yaitu pada mata pelajaran sejarah kebudayaan Islam (SKI) sampai saat ini masih dianggap sebagai mata pelajaran yang membosankan dan kurang diminati oleh sebagian siswa. Berdasarkan observasi awal peneliti yang dilakukan di MTs Kebunrejo Genteng, ternyata masih banyak kelemahan dan kendala yang dihadapi khususnya dalam pembelajaran (SKI). Berdasarkan hasil wawancara kepada sebagian siswa kelas VIII bahwa pemahaman mereka dalam proses pembelajaran dirasakan kurang karena sebagian besar dari mereka berasumsi bahwa mata pelajaran (SKI) merupakan mata pelajaran yang cenderung kurang menarik dan membosankan, karena siswa harus menghafal tahun ataupun nama-nama tokoh dan guru selalu menodong siswa pertanyaan di saat guru baru masuk kelas sehingga siswa merasa terbebani dalam mata pelajaran (SKI). Berdasarkan hasil wawancara kepada bapak Miftahur Rohman, S.Pd.I selaku guru mata pelajaran (SKI) itu adalah bentuk strateri guru yang berguna untuk mengevaluasi siswa agar tidak lupa dengan materi pelajaran yang di ajarkan minggu lalu, namun guru memang menyadari akan susahnya mata pelajaran (SKI), karena siswa dituntut untuk mengingat atau menghafal semisal pada materi dinasti Islam di situ ada nama-nama orang penting ataupun tahun-tahun.

Oleh karena itu dalam pembelajaran (SKI) sangat penting untuk memilih pendekatan, metode, media dan evaluasi yang tepat sehingga pembelajaran (SKI) berhasil dan tidak membuat siswa merasa bosan dan jenuh. Dengan memperhatikan metode yang baik, materi yang relevan, media yang mendukung, 
sumber yang relevan serta evaluasi sebagai tindak lanjut dari pembelajaran maka akan tercipta proses belajar mengajar yang interaktif.

Dari permasalahan di atas, maka wajar apabila mata pelajaran (SKI) dianggap mata pelajaran yang membosankan yang pada akhirnya berdampak kurangnya pemahaman siswa dalam menerima materi pelajaran. "kenyataan bahwa dalam pembelajaran ilmu-ilmu sosial seperti civics, sejarah, geografi, ekonomi dsb sering sekali mengundang rasa bosan dan menjenuhkan di kalangan siswa. Hal ini disebabkan beberapa faktor di antaranya adalah pertama, sifat ilmu sosial yang berbeda dengan ilmu alam atau eksakta. Kedua, bahasa dalam ilmu sosial dapat ditafsirkan dari berbagai sudut pandang (point of view) atau bersifat multi interpretation, lebih-lebih latar belakang siswa yang berbeda. Ketiga, buku teks ilmu sosial kurang menghubungkan teori dan kegiatan dasar manusia. Keempat, banyaknya isu-isu controversial dalam pelajaran ilmu-ilmu sosial" (Somantri et al., 2001)

Kondisi pembelajaran yang efektif adalah adanya minat dan perhatian siswa dalam belajar. Minat itu sendiri tumbuh apabila siswa merasa nyaman dan rileks di dalam proses pembelajaran(Usman, 2006). Dalam hal ini jelas bahwa peran guru dalam membawakan materi pembelajaran sangar berpengaruh terhadap siswa. Kita sering kali mendengarkan siswa yang kurang tertarik mengikuti beberapa mata pelajaran karena bosan dan mengantuk. Sebenarnya tidak ada pelajaran yang membosankan, akan tetapi guru yang membosankan karena kurang mengerti cara menyajikan materi dengan benar, menyenangkan dan menarik minat serta perhatian siswa (Gunawan, 2006).

Berdasarkan observasi kedua yang dilakukan pada siswa kelas VIII C di MTs Kebunrejo Genteng menunjukkan bahwa dalam kegiatan belajar mengajar mata pelajaran (SKI) materi dinasti Islam masih belum maksimal. Terutama nilai pada semester ganjil pada materi dinasti Islam mata pelajaran (SKI). Hal ini dapat dibuktikan dari 34 siswa yang ada 14 siswa memperoleh nilai di bawah Keriteria Ketuntasan Minimal (KKM) yaitu 7. Salah satu penyebab dari kurangnya nilai hasil belajar siswa kelas VIII C dikarenakan kurangnya minat belajar siswa dan guru belum maksimal dalam penggunaan media pembelajaran film dokumenter, bapak Miftahur Rohman selaku guru mata pelajaran (SKI) mengaku bahwa dalam penerapan media pembelajaran film dokumenter memang sudah pernah dilakukan dan berpendapat kurang efektif dilakukan untuk pembelajaran (SKI) dan lebih menekan untuk metode tanya jawab karena siswa mudah lupa sehingga dengan menggunakan metode tanya jawab itu bisa merangsang siswa agar tidak lupa dengan materi yang guru ajarkan pada minggu lalu. 
Kegiatan belajar mengajar seperti yang telah diuraikan di atas, yakni dominasi guru mata pelajaran (SKI) dalam menyampaikan materi menggunakan metode tanya jawab dan selalu menodong siswa pertanyaan di saat guru baru masuk kelas, dan meninggalkan penggunaan media karena siswa gaduh serta kurang memperhatikan.

Berdasarkan masalah di atas, peneliti bermaksud mendeskripsikan masalah tersebut dengan menggunakan suatu media pembelajaran yang dapat membantu siswa memahami konsep materi dinasti Islam mata pelajaran (SKI). Media pembelajaran yang akan digunakan adalah film dokumenter. Masalah tersebut akan diselesaikan melalui penelitian penggunaan media pembelajaran film dokumenter pada mata pelajaran (SKI) yang bertujuan untuk memudahkan siswa untuk memahami materi dinasti Islam serta minat belajar siswa pada mata pelajaran (SKI).

Media pembelajaran film dokumenter adalah media pembelajaran yang berupa film dokumenter dan temanya terfokus pada subjek-subjek sejarah dengan menggunakan alat bantu proyektor untuk ditampilkan di layar. Film dokumeter termasuk dalam media audiovisual karena di dalamnya terdapat audio dan visual. Film dokumenter adalah film yang tidak menciptakan suatu peristiwa, namun merekam peristiwa yang sungguh-sungguh terjadi (nyata) (Ummah, 2013: 13). Media audiovisual adalah media yang menggabungkan suara dengan gambar dalam pembelajaran, sehingga materi dapat tersampai dengan jelas kepada siswa (Ummah, 2013: 22). Dengan menggunakan media audiovisual berupa Media Pembelajaran Film Dokumenter diharapkan siswa kelas VIII C bisa lebih mudah untuk memahami dan menghafal materi pelajaran dinasty Islam (Ayyubiyah), minat belajar siswa lebih baik dari sebelumnya, dan siswa bisa mencapai nilai diatas (KKM) yaitu nilai 7.

\section{B. Metode Penelitian}

Penelitian ini merupakan penelitian kualitatif jenis deskriptif. Penelitian ini dilakukan pada bulan Januari sampai dengan bulan April 2019. Subyek penelitian adalah siswa kelas VIII C MTs Kebunrejo Genteng. Teknik pengumpulan data menggunakan observasi, wawancara, dan dokumentasi.

Analisa data yang digunakan yaitu perencanaan, tindakan, pengamatan, refleksi. Pengecekan keabsahan data dalam penelitian ini menggunakan Tringulasi sumber, Dimana data diperoleh dari empat sumber yaitu: Kepala Sekolah, Waka Kurikulum, Guru (SKI), dan Siswa kelas VIII C yang nantinya data tersebut dihubungkan dan disinkronkan. 


\section{Hasil dan Pembahasan}

Setelah dilakukan penelitian dan terkumpul data dari hasil wawancara, observasi, dan dokumentasi terkait Penggunaan Media Pembelajaran Film Dokumenter pada Mata Pelajaran (SKI) kelas VIII C Semester Genap di MTs Kebunrejo Genteng, peneliti mendapatkan hasil sebagai berikut:

1. Penggunaan Media Pembelajaran Film Dokumenter Pada Mata Pelajaran Sejarah Kebudayaan Islam (SKI) Pada Kelas VIII C Semester Genap di MTs Kebunrejo Genteng

Belajar dan pembelajaran adalah dua hal yang saling berhubungan erat dan tidak dapat dipisahkan dalam kegiatan edukatif. Belajar dan pembelajaran dikatakan sebuah bentuk edukatif yang menjadikan adanya suatu interaktif antara guru dengan siswa. Kegiatan belajar mengajar yang dikatakan dalam hal ini diarahkan untuk mencapai tujuan tertentu yang telah dirumuskan sebelum pengajaran dilakukan. Guru secara sadar merencanakan kegiatan pengajarannya secara sistematis dengan memanfaatkan segala sesuatunya untuk kepentingan dalam pengajaran (Pane \& Dasopang, 2017).

Proses belajar mengajar dapat diartikan sebuah kegiatan di mana terjadi penyampaian materi pembelajaran oleh guru kepada siswa, karenanya kegiatan pembelajaran ini sangat bergantung pada komponen-komponen yang ada di dalamnya. Dari sekian banyak komponen tersebut maka yang paling utama adalah adanya siswa, guru, media pembelajaran, materi pembelajaran, dan Rencana Pelaksanaan Pembelajaran (RPP). Keberadaan komponen tersebut dalam sebuah proses pembelajaran merupakan sebuah hal yang teramat penting karena komponen tersebut sangat bergantung satu sama lain. Misal tentang adanya guru yang berkualitas. Guru yang berkualitas merupakan sebuah hal yang cukup berpengaruh dalam proses pembelajaran. Guru tersebut berperan dalam mewujudkan sebuah situasi pembelajaran yang baik bagi para siswa, penggunaan Rencana Pelaksanaan Pembelajaran (RPP) pada proses pembelajaran berguna agar proses pembelajaran berjalan dengan rapi dan tersusun (berkonsep). Serta tenaga pendidik harus mampu menggunakan dan memaksimalkan adanya media pembelajaran guna meningkatkan pemahaman para siswa terkait dengan materi pelajaran yang disampaikannya. Jika hal tersebut dipahami sebagai sebuah kebutuhan dalam proses pembelajaran maka akan menjadikan sebuah kegiatan pembelajaran yang lebih berkualitas (Suwito, 2015).

Dalam suatu proses belajar mengajar baik yang berlangsung di dalam kelas maupun di luar kelas, seorang pendidik harus mengembangkan suatu 
pembelajaran yang menarik dan dapat dimengerti oleh siswa. Penggunaan media pembelajaran dalam proses belajar mengajar adalah hal yang sangat diperlukan saat proses belajar. Penggunaan media pembelajaran akan mempengaruhi kondisi siswa yang di ajar. Pemakaian media pembelajaran dalam proses belajar mengajar dapat membangkitkan minat dan keinginan yang baru, oleh karena itu penggunaan media pembelajaran sangat penting dalam mendukung proses belajar mengajar, sehingga perlu adanya pengembangan-pengembangan media pembelajaran. Penggunaan media pembelajaran pada mata pelajaran (SKI) di MTs Kebunrejo Genteng yang digunakan dan diterapkan adalah media pembelajaran film dokumenter, media pembelajaran film dokumenter ini adalah media yang melibatkan semua indera yaitu penglihatan, pendengaran, dan lain-lain. Media pembelajaran film dokumenter bisa menghasilkan suara dan gambar yang bergerak, sehingga penggunaan media pembelajaran film dokumenter ini sangat cocok pada mata pelajaran (SKI). Media pembelajaran film dokumenter ini sangat efektif diterapkan pada mata pelajaran (SKI) karena bertujuan khusus untuk memudahkan siswa dalam memahami serta menerima pembelajaran yang di berikan guru.

Penggunaan media pembelajaran film dokumenter pada mata pelajar (SKI) di MTs kebunrejo Genteng ini adalah menggunakan media pembelajaran film dokumenter. Media pembelajaran film dokumenter sangat efektif pada materi-materi mata pelajaran (SKI). Jadi guru menggunakan media pembelajaran film dokumenter ketika materi yang berkaitan dengan materi yang cocok.

Berikut keterangan yang disampaikan oleh Bapak Miftahur Rohman, S. Pd.I selaku guru mata pelajaran (SKI) mengenai Penggunaan Media Pembelajaran Film Dokumenter: "Media pembelajaran film dokumenter adalah media yang menayangkan sebuah film dokumenter. Dalam pembelajaran (SKI) ini saya menggunakan media pembelajaran film dokumenter yang menggunakan bantuan proyektor. Di dalam kelas sudah disediakan alat-alatnya, jadi saya bisa memutar film dokumenter dalam proses belajar mengajar. Karena saya rasa siswa akan lebih tertarik dengan video atau film ketika proses belajar mengajar. Anak-anak juga antusias sekali dalam mengikuti proses belajar mengajar. Apabila ini terkait materi mengenai sejarah-sejarah pada zaman dulu, jadi saya harus memikirkan bagaimana caranya agar siswa tidak bosan dan siswa mudah memahaminya. Jadi saya rasa media ini sangat cocok sekali pada mata pelajaran. Sebagai guru tentu saya harus selalu merancang berbagai cara untuk mengajar siswa jadi tidak 
dengan satu cara saja, setiap materi pelajaran yang ada saya membawakannya itu juga berbeda-beda caranya dan bahkan walaupun materi sama ketika kelasnya berbeda saya membawakan juga berbeda caranya. Jadi intinya menjadi guru itu tidak boleh malas, harus belajar setiap saat karena ketika kita sebagai guru bermalas-malasan nanti akan berdampak buruk kepada siswa, teknologi sekarang sudah beragam sehingga saya juga harus mengikuti perkembangan dalam mengajar. Dalam mata pelajaran (SKI) model penilaian yang saya gunakan lebih fokus ke nilai spiritual dan sikap jadi ketika ada siswa mendapat nilai di bawah Kriteria Ketuntasan Minimal (KKM) biasanya saya lihat untuk spiritual dan sikapnya bagaimana lalu siswa dibimbing untuk mengerjakan tugas tambahan".

Dalam wawancara di atas maka Bapak Miftahur Rohman menggunakan media yang dapat mempermudah siswa memahami dan tergugah untuk mengetahui isi materi dan tidak bingung dengan materi yang panjang. Hal ini dapat dibuktikan dengan hasil wawancara sebagai berikut: "Saya rasa dalam penggunaan media pembelajaran film dokumenter ini akan dapat membangkitkan minat agar siswa tidak bosan karena siswa lebih tertarik dengan video atau film ketika proses belajar mengajar, memudahkan pemahaman dalam proses belajar, jadi siswa juga cepat memahami, dan saya sebagai guru (SKI) juga mudah dalam menjelaskan materi, karena materinya berisi sejarah yang cukup sulit untuk dipahami, dihafalkan, maka dari itu saya menggunakan media pembelajaran film dokumenter ini".

Dalam wawancara di atas dapat dijelaskan bahwa media pembelajaran film dokumenter adalah media yang dapat memudahkan guru dan siswa dalam melakukan proses belajar mengajar terutama dalam hal mata pelajaran (SKI) yang sedikit dipahami siswa karena materinya terlalu banyak dan menyita waktu. Dengan media pembelajaran ini maka diharapkan siswa senang mengikuti proses pemelajaran (SKI).

Proses pembelajaran dimulai dari persiapan, pelaksanaan pembelajaran, kemudian evaluasi. Sebelum pembelajaran berlangsung guru telah menyiapkan Rencana Pelaksanaan Pembelajaran (RPP) yang akan digunakan oleh guru untuk mengajar. Hal ini sebagaimana dipaparkan oleh Ibu Indah Rofi'atin, S. Si selaku waka kurikulum MTs Kebunrejo Genteng kepada peneliti ketika melakukan wawancara bahwasannya: "Semua guru diharuskan membuat Rencana Pelaksanaan Pembelajaran (RPP) karena secara periodik ada control atau supervise dari kepala sekolah tentang bagaimana guru mengajar. RPP sendiri sangat penting karena di dalam RPP terdapat kompetensi dasar dan indikator yang harus disampaikan kepada siswa, 
terdapat tujuan pembelajaran, metode, media, serta bagaimana cara mengevaluasi para siswa. RPP juga merupakan arahan seorang guru untuk melaksanakan pembelajaran, maka dengan RPP kegiatan pembelajaran di kelas juga akan berjalan dengan rapi dan tersusun. Maka di sini setiap guru diharuskan membuat RPP untuk kegiatan pembelajaran”.

Berikut keterangan yang disampaikan oleh Bapak Miftahur Rohman selaku guru (SKI) kepada peneliti ketika melakukan wawancara, di mana beliau mengatakan: "Ya seperti biasa sebelum kita mengajar yang disiapkan yaitu silabus dan Rencana Pelaksanaan Pembelajaran (RPP). Kalau silabus memang sudah ada dari pusat, tidak perlu buat sendiri. Itu sudah diambil dari kurikulum, itu patokan dari pemerintah. Standar yang akan disampaikan kepada murid itu sudah ada di silabus. Tetapi kalau RPP itu sebetulnya penjabaran dari silabus, itu tergantung bagaimana kita memodifikasi tapi yang pasti harus sesuai dengan yang sudah ada di silabus. RPP itu fleksibel sesuai dengan kebutuhan kita saat mengajar di kelas, jadi setiap orang membuat RPP itu bebas sesuai dengan tujuan pembelajaran yang ingin dicapai. Yang kedua yang harus disiapkan yakni media, media ini sesuai dengan materi yang akan disampaikan. Dalam hal ini mbak, saya memasukkan materi dinasti Islam (Ayyubiyah) itu bukan hanya teorinya saja, saya juga menyiapkan media yang sesuai dengan materi yang saya ajarkan. Jadi siswa gampang memahami karena tau secara nyata kisah Dinasti Islam (Ayyubiyah) dan siswa tidak bosan dalam proses belajar mengajar.

Dalam wawancara di atas dapat dijelaskan Guru membuat RPP tergantung kebutuhan dan kesesuaian dengan materi, seperti dalam KD 3.1 Memahami sejarah berdirinya dinasti Islam (Ayyubiyah). Jadi tujuan pembelajaran bisa fokus kepada siswa untuk memahami sejarah berdirinya dinasti Islam (Ayyubiyah). Membuat RPP sangat penting dilakukan karena terkait dengan konsep guru mengajar siswa dengan baik. RPP berisikan tentang pembahasan materi ditempuh berapa pertemuan, alokasi waktu, tujuan pembelajaran, kompetensi dasar, metode, Strategi, alat atau bahan, media pembelajaran, dan prosedur-prosedur pembelajaran yang akan dilakukan.

Hal tersebut sejalan dengan hasil observasi yang dilakukan oleh peneliti pada saat proses pembelajaran mata pelajaran (SKI) di kelas VIII C. Sebelum pembelajaran guru sudah menyiapkan Rencana Pelaksanaan Pembelajaran (RPP) sesuai dengan kebutuhan, kesesuaian dengan materi pembelajaran, yakni dalam KD 3.1 materi "Menjelaskan sejarah berdirinya dinasti Islam (Ayyubiyah)". Jadi tujuan pembelajaran bisa fokus kepada siswa untuk 
memahami sejarah berdirinya dinasti Islam (Ayyubiyah). Pada saat pembelajaran berlangsung dalam menjelaskan materi guru juga menggunakan media pembelajaran untuk memudahkan siswa memahami materi yang diajarakan oleh guru. Dalam KD 3.1 materi "Menjelaskan sejarah berdirinya dinasti Islam (Ayyubiyah)" guru menggunakan media pembelajaran film dokumenter (menayangkan film dokumenter dinasti Islam (Ayyubiyah). Membuat RPP sangat penting dilakukan karena terkait dengan konsep guru mengajar siswa dengan baik. RPP berisikan tentang pembahasan materi ditempuh berapa pertemuan, alokasi waktu, tujuan pembelajaran, kompetensi dasar, metode, Strategi, alat atau bahan, media pembelajaran, dan prosedurprosedur pembelajaran yang akan dilakukan.

Dalam proses belajar mengajar guru harus lebih kreatif dalam penggunaan media pembelajaran untuk materi pembelajaran. Mengajar adalah kegiatan yang terencana dengan melibatkan siswa. Dalam penelitian ini telah didapatkan data mengenai penggunaan media pembelajaran film dokumenter pada mata pelajaran (SKI), sebagaimana hasil penelitian yang didapatkan oleh peneliti dari wawancara dengan Bapak Miftahur Rohman selaku guru mata pelajaran (SKI) mengenai Penggunaan Media Pembelajaran Film Dokumenter. Jadi proses belajar mengajar menggunakan media pembelajaran film dokumenter bertujuan untuk membangkitkan minat agar siswa tidak bosan, siswa lebih tertarik dengan video atau film ketika proses belajar mengajar menurut bapak Miftahur Rohman selaku guru mata pelajaran (SKI), dan siswa mudah untuk memahami materi pembelajaran khususnya materi-materi dinasti Islam (Ayyubiyah), oleh karena itu penggunaan media pembelajaran sangat penting dalam mendukung proses belajar mengajar.

Penggunaan media pembelajaran merupakan keterampilan penting yang harus dimiliki oleh guru dalam proses belajar mengajar di kelas. Namun guru harus pandai-pandai memilih media pembelajaran yang tepat dalam proses belajar mengajar, karena penggunaan sebuah media pembelajaran akan sangat berpengaruh dalam kualitas pembelajaran. Di MTs Kebunrejo Genteng ini guru sudah menggunakan media pembelajaran film dokumenter untuk menghindari siswa bosan dalam menerima pembelajaran di kelas. Media pembelajaran film dokumenter merupakan media pembelajaran yang berupa film dokumenter dan temanya berfokus pada subyek-subyek sejarah dengan menggunakan alat bantu proyektor untuk menampilkan di layar. Film dokumenter bukan merupakan pengulangan suatu kejadian, melainkan kejadian yang nyata dengan masyarakat dan situasi-situasi yang nyata pula (Ummah, 2013: 13). Tujuannya adalah untuk membangkitkan minat agar 
siswa tidak bosan karena siswa lebih tertarik dengan video atau film ketika proses belajar mengajar menurut bapak Miftahur Rohman selaku guru mata pelajaran (SKI), dan siswa mudah untuk memahami materi pembelajaran khususnya materi-materi dinasti Islam (Ayyubiyah). Dalam penggunaan media pembelajaran film dokumenter dalam pembelajaran harus tersusun berdasarkan rencana yang jelas dan didasarkan pada tujuan pembelajaran. Untuk mencapai tujuan tersebut guru dituntut untuk kreatif agar proses pembelajaran berjalan dengan lancar.

Penggunaan Media Pembelajaran Film Dokumenter ini memiliki tujuan antara lain: 1) untuk membangkitkan minat agar siswa tidak bosan saat proses belajar mengajar, 2) untuk memudahkan siswa memahami materi pembelajaran khususnya materi-materi dinasti Islam (Ayyubiyah), 3) untuk memudahkan siswa menghafal tokoh-tokoh yang ada di dinasti Islam (Ayyubiyah).

Dengan memahami tujuan yang diperoleh dengan menerapkan media pembelajaran film dokumenter, seorang guru diharapkan memiliki keterampilan dalam proses belajar mengajar yang akan dilakukannya. Hasilnya bukan hanya untuk siswa saja tetapi guru juga merasakannya. Dengan begitu guru dan siswa sama-sama mendapat sebuah keuntungan dalam proses belajar menggunakan media pembelajaran film dokumenter.

Dari hasil wawancara oleh Bapak Miftahur Rohman selaku guru mata pelajaran (SKI) mengenai langkah-langkah proses belajar mengajar mata pelajaran (SKI) melalui penggunakan media pembelajaran film dokumenter meliputi tiga tahap.

Adapun tahap-tahap tersebut antara lain:

a) Tahap persiapan

Tahap persiapan merupakan awal dari semua proses suatu pelaksanaan kegiatan yang bersifat rasional. Perencanaan pembelajaran berisi tentang rangkaian kegiatan yang harus dilaksanakan untuk mencapai tujuan. Oleh karena itu perencanaan pembelajaran dapat berfungsi sebagai pedoman dalam mendesain pembelajaran sesuai dengan kebutuhan. Untuk penggunaan media pembelajaran film dokumenter dalam proses pembelajaran perlu perencanaan secara sistematis agar tercapai tujuan pembelajaran secara optimal. Dalam hal ini, kegiatan persiapan yang dilakukan oleh guru yaitu: a) menyusun Rencana Pelaksanaan Pembelajaran (RPP) yang dijadikan sebagai pedoman dalam proses pembelajaran yang akan dilakukan, b) menyiapkan media pembelajaran yang akan digunakan untuk menyampaikan materi, c) menentukan metode yang sesuai dengan materi yang sedang di ajarkan. 
b) Tahap pelaksanaan

Dalam pelaksanaan proses pembelajaran, kemampuan yang di tuntut adalah kreativitas guru dalam menciptakan dan menumbuhkan kegiatan siswa belajar sesuai dengan rencana yang telah disusun dalam tahap persiapan. Dalam tahap ini kegiatan yang dilakukan oleh guru dan siswa adalah sebagai berikut: a) guru menghidupkan proyektor dan laptop, b) guru menyesuaikan proyektor dengan layar, c) guru memasang kabel proyektor pada laptor sampai laptop terhubung dengan proyektor, d) setelah proyektor terhubung dengan laptor, buka bahan film dokumenter dinasti Islam (Ayyubiyah), e) guru memasang kabel speaker pada leptop agar suara film dokumenter bisa terdengar oleh semua siswa, f) guru menggunakan pen power point untuk menjelaskan pokok-pokok dalam film dokumenter, g) siswa menyimak film dokumenter dan mencatat pokok materi.

c) Tahap evaluasi

Tahap evaluasi ini merupakan proses sistematis yang meliputi pengumpulan informasi (angka, deskripsi verbal) analisis dan interpetasi informasi untuk membuat keputusan tentang pencapaian hasil belajar siswa berdasarkan pada standar yang ditetapkan. Evaluasi dilakukan oleh guru guna untuk mengukur sejauh mana siswa telah memahami dan mengetahui suatu materi yang telah siswa pelajari. Evaluasi ini dilakukan dengan banyak cara seperti penilaian spiritual, sikap, dan pemberian tugas dengan didampingi oleh guru.

Berdasarkan teori yang menyebutkan demikian, maka peneliti dapat menyimpulkan bahwa upaya guru dalam proses belajar mengajar dengan menggunaan media pembelajaran film dokumenter di MTs Kebunrejo Genteng dilakukan melalui tiga tahap, meliputi tahap persiapan, pelaksanaan, dan evaluasi.

Jadi dapat ditarik kesimpulan, bahwa dengan adanya proses pembelajaran menggunakan media pembelajaran film dokumenter memberikan dampak yang lebih bagus dalam pembelajaran (SKI) di MTs Kebunrejo Genteng, karena guru mudah dalam mengajar dan siswa merasa lebih nyaman dan mudah paham dengan materi yang disampaikan. Dengan begitu siswa akan bersungguh-sungguh untuk menerima pelajaran dan membangkitkan minat siswa untuk belajar untuk mendapatkan prestasi yang lebih bagus, dan unggul dalam pelajaran. Sehingga menjadikan proses pembelajaran (SKI) dapat berjalan dengan baik, efektif dan juga efisien.

\section{Aktivitas Belajar Siswa dalam Penggunaan Media Pembelajaran Film}




\section{Dokumenter pada Mata Pelajaran (SKI) Kelas VIII C Semester Genap di MTs Kebunrejo Genteng}

Dalam penggunaan media pembelajaran film dokumenter pada mata pelajaran (SKI) kelas VIII C semester genap di MTs Kebunrejo Genteng, aktivitas belajar siswa terlihat sangat baik, karena dapat dilihat dari antusias siswa dalam mengikuti proses belajar mengajar serta siswa mau menyimak film dokumenter yang ditayangkan oleh guru dari awal sampai akhir. Guru menggunakan media pembelajaran film dokumenter karena media tersebut cocok dengan materi yang membahas terkait sejarah-sejarah yang susah untuk dipahami dan diminati oleh siswa, sehingga dengan penggunaan media pembelajaran film dokumenter ini dapat memudahkan siswa untuk memahami materi pembelajaran serta dapat membuat siswa tidak bosan pada saat proses pembelajaran.

Sebagai guru tentu harus selalu merancang berbagai cara untuk mengajar siswa dengan benar, jadi tidak dengan satu cara saja melainkan harus dengan banyak cara sehingga keberhasilan dalam proses pembelajaran bisa didapatkan. Bapak Miftahur Rohman selaku guru mata pelajaran (SKI) berpendapat, Melalui pemutaran film dokumenter untuk materi dinasti Islam (Ayyubiyah) siswa bisa cepat memahami materi ini, karena pada film dokumenter ini saya memilih sesuai dengan materi yang dipelajari siswa yaitu terkait sejarah berdirinya dinasti Islam (Ayyubiyah). Sebelum saya menayangkan film dokumenter saya menjelaskan tujuan pembelajaran terlebih dahulu dan mengarahkan siswa untuk memperhatikan penayangan film dokumenter. Karena saya rasa siswa akan lebih tertarik dengan video atau film ketika proses belajar mengajar dan terlihat untuk aktivitas belajar siswa dari antusias sekali dalam mengikuti proses belajar mengajar serta siswa mau menyimak film dokumenter. Apabila ini terkait materi mengenai sejarahsejarah pada zaman dulu, jadi saya harus memikirkan bagaimana caranya agar siswa tidak bosan dan siswa mudah memahaminya. Jadi saya rasa media ini sangat cocok sekali pada mata pelajaran (SKI). Sebagai guru tentu saya harus selalu merancang berbagai cara untuk mengajar siswa jadi tidak dengan satu cara saja, setiap materi pelajaran yang ada saya membawakannya itu juga berbeda-beda caranya dan bahkan walaupun materi sama ketika kelasnya berbeda saya membawakan juga berbeda caranya.

Jadi di sini intinya menjadi guru itu tidak boleh malas, harus belajar setiap saat karena ketika kita sebagai guru bermalas-malasan nanti akan berdampak buruk kepada siswa. pendapat dari Bapak Miftahur Rohman diperkuat dengan pendapat dari siswa kelas VIII C, Onas Bagawan Saputra, Ya 
biasanya ya mas, kalau Bapak Rohman ketika mengajar selalu menyiapkan media pembelajaran yang sesuai dengan materi yang kita pelajari. Jadi kita lebih paham dan lebih mengerti materi yang sedang diajarkan. Misalnya waktu materi dinasti Islam (Ayyubiyah) Bapak Rohman menggunakan media pembelajaran berupa film dokumenter yang isinya menjelaskan tentang materi tersebut. Jadi kita tidak hanya belajar dari buku saja, kita menjadi lebih mengetahui dengan ditayangkannya film dokumenter tersebut, dan M. Insan Fadli El Maura, Saya senang mas diajar Bapak Rohman, karena setiap mengajar selalu jelas dan sesuai dengan materi yang sedang dipelajari. Bukan hanya bercerita saja tetapi menggunakan media pembelajaran yang menarik. Jadi kita lebih mudah memahami dan menghafal tokoh-tokoh yang ada di dinasti Islam (Ayyubiyah), soalnya untuk menghafal itu tidak mudah mas.

Dalam dunia pendidikan, semua mengetahui bahwa tugas guru bukan hanya mengajar dan memberi ilmu pengetahuan saja kepada siswa, tetapi lebih dari itu, yakni mengembangkan potensi yang ada pada siswa, memberikan pengetahuan yang luas kepada siswa, serta memberikan kebebasan kepada siswa untuk berfikir.

Menjadi seorang guru itu tidak hanya menggunakan metode, dengan perkembangan teknologi maka seorang guru juga harus bisa mengikutinya, apalagi teknologi itu bisa bermanfaat dalam pembelajaran. Guru harus membuat program pembelajaran yang menarik dimana siswa ketika mengikuti pembelajaran tidak bosan, dan tidak monoton. Apalagi yang kita ketahui bahwa mata pelajaran (SKI) ini sangat penting untuk siswa, karena dalam mata pelajaran (SKI) siswa dapat mempelajari dan mengetahui sejarahsejarah tentang Islam.

\section{Kesimpulan}

Penggunaan media pembelajaran film dokumenter pada mata pelajaran (SKI) kelas VIII C semester genap di MTs Kebunrejo Genteng merupakan proses pembelajaran menggunakan media pembelajaran film dokumenter yang bertujuan untuk membangkitkan minat belajar agar siswa tidak bosan karena siswa lebih tertarik dengan video atau film, dan dengan penggunaan media pembelajaran film dokumenter siswa mudah untuk memahami materi pembelajaran khususnya pada materi-materi dinasti Islam (Ayyubiyah).

Aktivitas belajar siswa kelas VIII C MTs Kebunrejo Genteng dalam penggunaan media pembelajaran film dokumenter pada proses pembelajaran (SKI) ini sangat baik terlihat dari antusias siswa dalam mengikuti pembelajaran (SKI), jadi siswa memperhatikan film dokumenter yang di tayangkan oleh guru 
Riza Faishol, Ahmad Izza Muttaqin \& Mohammad Afton Fahmi Prayogie

mulai awal sampai akhir, serta siswa juga sering bertanya ketika ada materi yang kurang difahami. Penggunaan media pembelajaran film dokumenter dalam proses belajar mengajar dapat membangkitkan minat agar siswa tidak bosan karena siswa lebih tertarik dengan video atau film serta memudahkan siswa untuk memahami materi yang dipelajarinya atau dihafalkan.

Faktor penghambat dan faktor pendukung dalam penggunaan media film dokumenter pada pembelajaran (SKI) yaitu pada faktor penghambat adanya kendala siswa bergurau dan tidak memperhatikan dalam proses belajar mengajar ini terkait siswa yang minat untuk belajarnya masih kurang dan fasilitas sekolah seperti alat bantu proyektor yang masih belum ada di semua kelas jadi untuk kelas yang tidak ada proyektor siswa harus mengambil di ruang lab. computer terlebih dahulu dan itu akan memakan waktu yang tidak sebentar sehingga dalam masalah waktu untuk proses belajar mengajar berkurang.

Sedangkan untuk faktor pendukung yaitu pada guru sudah mampu untuk menjalankan media pembelajaran film dokumenter, guru tidak malas untuk berkreasi dalam proses belajar mengajar, siswa akan lebih mudah memahami isi materi karena dengan adanya film dokumenter siswa melihat langsung tokohtokoh yang namanya mereka hafalkan jadi sumber belajar siswa tidak hanya dari buku saja melainkan media pembelajaran.

\section{Daftar Rujukan}

Astuti, F. Y., Faishol, R., \& Trianingsih, R. (2020). PENGARUH PEMANFAATAN PERPUSTAKAAN SEKOLAH TERHADAP MINAT BACA PADA MATA PELAJARAN SKI KELAS XI AGAMA DI MAN 2 BANYUWANGI. Ar-Risalah: Media Keislaman, Pendidikan Dan Hukum Islam, 18(1), 54-82.

Dewi, N. L., Muttaqin, A. I., \& Muftiyah, A. (2019). IMPLEMENTASI STRATEGI INFORMATION SEARCH DENGAN MEMAKSIMALKAN PENGGUNAAN SMARTPHONE DALAM PEMBELAJARAN PAI KELAS X MIPA 1 DI SMA NEGERI 1 GENTENG TAHUN PELAJARAN 2018/2019. Tarbiyatuna: Kajian Pendidikan Islam, 3(2), 82-96.

Gunawan, A. W. (2006). Genius learning strategy. Jakarta: Pustaka Utama.

Pane, A., \& Dasopang, M. D. (2017). Belajar dan pembelajaran. Fitrah: Jurnal Kajian Ilmu-Ilmu Keislaman, 3(2), 333-352.

Sisdiknas, U.-U. (2003). UU RI No. 20 Tahun 2003. Jakarta: Sinar Grafika.

Somantri, M. N., Indonesia, U. P., Supriadi, D., \& Mulyana, R. (2001). Menggagas pembaharuan pendidikan IPS: menandai 70 tahun usia Prof. Muhammad 
Riza Faishol, Ahmad Izza Muttaqin \& Mohammad Afton Fahmi Prayogie

Numan Somantri, M. Sc., guru besar senior PPS dan FPIPS UPI. Diterbitkan atas kerjasama Program Pascasarjana dan FPIPS UPI dengan PT ....

Suwito, A. (2015). Pendekatan parade untuk meningkatkan aktivitas dan hasil belajar peserta didik tentang materi sistem pemerintahan melalui pemanfaatan media voucher pada kelas XII IPS 2 SMA Negeri 1 Lasem. CIVIS, $5(2 / \mathrm{JULI})$.

Usman, H. (2006). Manajemen: teori, praktik, dan riset pendidikan. Jakarta: Bumi Aksara. 